\title{
Differences in Physicochemical Properties of Water from Neighbourhood Boreholes and Their Usefulness in Clarias gariepinus Egg Hatching
}

\author{
*UKA, A; KALU, SE \\ Department of Fisheries and Aquatic Resources Management, College of Natural Resources and Environmental Management, \\ Michael Okpara University of Agriculture, Umudike, Nigeria \\ *Correspondence Author Email: anayaeleuka@gmail.com
}

\begin{abstract}
Water parameters and egg hatching success in water from three boreholes within close proximity were investigated. The studies were conducted to ascertain differences in their quality and ability to support Clarias gariepinus egg hatching. The boreholes were tagged $300 \mathrm{~m}, 400 \mathrm{~m}$ and $330 \mathrm{~m}$ in relation to their distances from a perennial stream within the vicinity. Temperature and $\mathrm{pH}$ were investigated using digital metres. Dissolved oxygen, alkalinity and total hardness were determined using titration method. The water parameters were measured twice a week for 5 weeks. Percentage egg hatching, time to commencement and termination of egg hatching were studied in triplicates. The results obtained showed that $\mathrm{pH}$, Dissolve oxygen (DO), Alkalinity and total hardness were significantly different $(\mathrm{P}<0.05)$ among the boreholes, while temperature was not significantly different $(\mathrm{P}>0.05)$. Total hardness fluctuated most at $21 \%$ coefficient of variation $(\mathrm{CV})$. Egg fertilization success was not significantly different $(\mathrm{P}>0.05)$. Percentage egg hatching $(68.8 \%, 92.8 \%$ and $87.3 \%$ for $300 \mathrm{~m}, 400 \mathrm{~m}$ and $330 \mathrm{~m})$ respectively was significantly different $(\mathrm{P}<0.05)$. Higher coefficient of variation in hardness enhanced egg hatching. It could be induced in hatchery operations. Time to commencement (1443, 1453 and 1517) minutes and termination of hatching (1962, 1957 and 2037) minutes were significantly different $(\mathrm{P}<0.05)$. Larval survival by day-3 post hatch was significant [y different $(\mathrm{P}<0.05)$. The study provided evidence of disparity in water quality among the boreholes and revealed differences in their ability to support Clarias gariepinus egg hatching. These suggest carefulness in choice of borehole water for fish egg hatching regardless of proximity of boreholes.
\end{abstract}

\section{DOI: $\underline{\text { https://dx.doi.org/10.4314/jasem.v23i8.22 }}$}

Copyright: Copyright (C) 2019 Uka and Kalu. This is an open access article distributed under the Creative Commons Attribution License (CCL), which permits unrestricted use, distribution, and reproduction in any medium, provided the original work is properly cited.

Dates: Received: 30 May 2019; Revised: 12 August 2019; 28 August 2019

Key words: Catfish, Propagation, Water and Egg

The gap between demand and supply of fish in Nigeria has continued to widen, making fish unaffordable to most Nigerians (Olayinka, 2013). The annual fish demand in Nigeria as at 2012 was 2,656,739 tonnes when the domestic production was reported at 700,739 tonnes (Ayinla, 2012). Ekeleme, (2013) reported that the country spends a whooping sum of one hundred and fifteen million, nine hundred and eight four thousand, eight hundred US dollars $(115,984,800 \$)$ annually to make up for the short fall in fish production. The current fish production in the country is a far cry from her potential being a coastal state. Nigeria is bordered in the south by the Atlantic Ocean with about 1.8 million hectares of fresh and brackish water swamps site suitable for aquaculture production (FAO, 1994). The country is therefore, endowed with extensive inland water systems - lakes, reservoirs, lagoons, creeks and floodplains all of high potential for fish production. Ayoade and Oyebande (1983) posited that Nigeria has extensive lake and reservoir systems covering about 300,000 hectares. This reveals a tremendous aquaculture potential of the geographic
Nigeria. Major constraints to aquaculture development and by extension fish production in Nigeria include scarcity of fish seeds and fish food as well as inadequate database on the biology and ecological requirement of endemic fish species with aquaculture potentials which hampers rational aquaculture development plan (Olayinka, 2013). Fish seeds are very expensive in Nigeria. It constitutes a major operational cost of about 20\% (Abiodun, 1986). Therefore adequate fish seeds are unavailable to most farmers in Nigeria. Orji (1997) traced scarcity of fish seeds in Nigeria to the fact that fish spawning is affected greatly by the physico-chemical parameters of the water used in most hatcheries in the country. Several other authorities also reported physicochemical qualities of water to influence egg hatching and subsequent development of hatched fish egg after breeding (Meador and Goldstein 2003, Allen 2001, Giller and Malmqrisit 2002). Water is considered as a material in which dissolved gases, inorganic substances (minerals) as well as organic matter are abundant. In addition to dissolved 
substances, water matrix gives buoyance and other supports to microorganisms, plants and animals and provides a medium of exchange for these populations (Boyd and Tucker, 1992). Water quality can be broadly defined as the physical, chemical and biological composition of water as related to its intended use. A good water quality for aquaculture must satisfy the minimum requirement for the survival, reproduction and growth of cultivable fish species (Onuoha, 2009). Quality of water is influenced by the source of the water. According to Lee (1973), good quality water is free of pesticides, has a suitable $\mathrm{pH}$ and is free of harmful elements, such as pollution or excessive mineral content. The sources of water may be surface water such as river, rain or settled run-offs or underground water such as borehole and well. Underground water is usually pollution free, although some underground waters contain noxious gases that can be toxic to aquatic organisms. Hydrogen sulphide and methane are the most common undesirable gases (Wheaton 1977). Tucker (1991) reported that the underground water is the best water for hatcheries because they are usually free of pollutants, suspended solids and diseases. The major disadvantage of underground water is its low oxygen content. All surface water suffers the disadvantage of being exposed to sources of pollution (Wheaton 1977). Factors that could bring about differences in water quality among neighbourhood boreholes includes (i) disparity in distance to the aquifer even within near locations. This makes it very difficult to have a standard distance to drill a borehole. Some Engineers do not get to the right aquifer while drilling a borehole. (ii) Difference in soil contaminants. Soil that has lots of iron (ferrous soil) will contaminate the water with iron. (iii) Anthropogenic activities of farming, waste dump and mining. Some soils were used for farming, whereas some were used as a dump site, others were used for mining of different minerals. The type of contaminants seen on the mining site is different from the one seen on the dump site likewise the one seen on a farmland (Shiklomanov, 2000). All these contaminants create disparity in the physico-chemical properties of water from different boreholes. Clarias gariepinus is one of the most important tropical catfish species for Aquaculture. Its distribution ranges from Nile to West Africa and from Algeria to South Africa (Emmanuel and Solomon, 2011). The fertilized eggs of $C$. gariepinus will hatch within $24-28$ hours when placed in conducive environment (Piper et al., 1982). The study reported here compared some water quality parameters among three bore holes in Michael Okpara University of Agriculture and assessed their suitability for use in hatchery propagation of Clarias gariepinus in the University.

\section{MATERIALS AND METHODS}

Studied borehole waters: Water parameters and egg hatching success in water from three neighbourhood boreholes within the premises of Michael Okpara University of Agriculture, Umudike $\left(5.467^{\circ} \mathrm{N}, 7\right.$. $\left.489^{\circ} \mathrm{E}\right)$ were studied. The three boreholes were tagged FARM-200m $\quad\left(5.481^{\circ} \mathrm{N}, 7.537^{\circ} \mathrm{E}\right), \quad$ CNREM-300m $\left(5.477^{\circ} \mathrm{N}, 7.539^{\circ} \mathrm{E}\right)$ and HOSTEL-230m $\left(5.495^{\circ} \mathrm{N}, 7.548^{\circ} \mathrm{E}\right)$ in relation to their exact location and distances from a perennial stream (Anya stream) within the vicinity. The three boreholes (FARM300m, CNREM-400m and HOSTEL-330m) were simply reported in this document as $300 \mathrm{~m}, 400 \mathrm{~m}$ and $330 \mathrm{~m}$ respectively.

Sample collection and analysis: Sample bottles of $120 \mathrm{cl}$ (individual capacity) were used for the study. The sample bottles were sterilized with $70 \%$ alcohol and were flushed for 2 minutes to ensure thorough washing. The samples were transported to laboratory for analysis in an ice-packed cooler. The physicochemical properties analysed in the laboratory included Dissolved Oxygen (DO), Total alkalinity and total hardness. Temperature and $\mathrm{pH}$ were measured in-situ using mercury in glass thermometer and $\mathrm{pH}$ metre (Hanna equipment) respectively.

Dissolved oxygen (DO): The dissolved oxygen was measured following Winkler titration method. $25 \mathrm{ml}$ of water sample was added into $100 \mathrm{ml}$ beaker and 2 $\mathrm{ml}$ Magnesium sulphate $\left(\mathrm{MnSO}_{4}\right)$ was then added followed with the addition of $2 \mathrm{ml}$ of alkaline potassium iodide. The bottle was immediately covered with a stopper resulting in formation of brown precipitate. The stopper was removed and $2.0 \mathrm{ml}$ of concentrated sulphuric acid $\left(\mathrm{H}_{2} \mathrm{SO}_{4}\right)$ was added. The acid was allowed to run down the neck of the bottle and a golden yellow solution was obtained. A freshly prepared starch was added and a bluish black solution was obtained. The bluish black colour solution was titrated with $0.025 \mathrm{~N}$ sodium thiosulphate until solution turns to a pale straw to colourless end point at the first disappearance of the blue colour. Dissolved Oxygen was then estimated using the formula:

$$
\text { DO }=\frac{\mathrm{A}}{\mathrm{B}} \times \frac{C}{\mathrm{D}}
$$

$\mathrm{A}=$ Mliliter of titrant $\times 0.025 \mathrm{~N} \times 8 \times 100 \mathrm{mg} / 1 ; \mathrm{B}=$ vol. $g$ water sample; $\mathrm{C}=$ mole of water sample -4 ; $\mathrm{D}=$ vol of bottle; $\mathrm{N}=$ Normality of $\mathrm{Na}_{2} \mathrm{~S}_{2} \mathrm{O}_{3} ; 8=$ Oxygen cone equivalent to $1 \mathrm{ml}$ of $\mathrm{I} \mathrm{N} ; 1000=$ conversion factor to 1 litre

Determination of total hardness: The total hardness was measured using the Winklers titration method. 
$25 \mathrm{ml}$ of water sample was placed in $250 \mathrm{ml}$ clean conical flask and $3 \mathrm{ml}$ of Ammonium chloride was added followed with addition of 2 drops of Eriochrome Black $\mathrm{T}$ indicator. This was titrated against $0.01 \mathrm{M}$ EDTA solution until there was a colour change from violet to blue. Hardness was then estimated from the formula:

$$
\mathrm{H}=\frac{V \times M \times 1000}{m l \text { of sample used }}
$$

Where $\mathrm{H}=$ Hardness in $\mathrm{mg} / \mathrm{l} \mathrm{CaCO}_{3} ; \mathrm{V}=$ Volume of EDTA used and $\mathrm{M}=$ Molarity of EDTA used

Alkalinity: The reagents used were concentrated sulphuric acid $\left(\mathrm{H}_{2} \mathrm{SO} 4\right)$, Distilled water and Phenolphthalin indicator. $30 \mathrm{ml}$ of conc. $\mathrm{H}_{2} \mathrm{SO}_{4}$ was mixed with 1 litre of distilled water to obtain the stock solution. $20 \mathrm{ml}$ of the stock solution was diluted and thoroughly mixed in I litre of distilled water to have $0.02 \mathrm{~N} \mathrm{H}_{2} \mathrm{SO}_{4}$. The $0.02 \mathrm{~N} \mathrm{H}_{2} \mathrm{SO}_{4}$ was poured into a burette for titration against $100 \mathrm{ml}$ of sample water in a conical flask. 10 drops of phenolphthalein indicator was added to the sample water and a pink solution was obtained. Titration was until colourless end point was achieved. Phenophthalein alkalinity was estimated from titration volume x 10 as ppm $\mathrm{CaCO}_{3}$.

Egg hatching in water from different boreholes: Eggs from a female $C$. gariepinus were fertilized with milt from single male of the same species and incubated in triplicate water from three different boreholes. Percentage egg hatching, time to commencement and time to termination of egg hatching were investigated. Egg fertilization was recognized from the distinct green colour of the fertilized egg against the white colouration of the un-fertilized eggs while hatching was recognized on observation of shaking and tail wagging of hatchling as against non-movement of the un-hatched eggs (Uka and Sikoki, 2011).

\section{RESULT AND DISCUSSION}

The temperature of water $(28,28.5$ and 28.56$){ }^{\circ} \mathrm{C}$ from the three boreholes $(300 \mathrm{~m}, 400 \mathrm{~m}$ and $330 \mathrm{~m}$ respectively) and their corresponding fluctuation $(9.1 \%, 8.8 \%$ and $8.8 \%$ within the boreholes) were not significantly different $(\mathrm{P}>0.05)$ (tables 1 and 2$)$. This could be attributed to the relative uniform environment of the boreholes. The environment of the boreholes consisted of sparse vegetation and objects that occasionally cast their shadow on the overhead tanks. There was no permanent artificial object to prevent exposure of the overhead tanks to sunray source of heat. The slight differences observed could come from irregular shading offered by vegetation for different duration depending on the direction of wind and position of the sun. Bhatnagar and Devi (2013) recognised the role of providing shades in preventing heat-up of borehole water.

Table 1: Water Quality Parameters of three neighbourhood boreholes

\begin{tabular}{lllll}
\multicolumn{5}{c}{ Table 1: Water Quality Parameters of three neighbourhood boreholes } \\
\hline \multicolumn{4}{c}{ Boreholes } \\
\hline Parameters & $300 \mathrm{~m}$ & $400 \mathrm{~m}$ & $330 \mathrm{~m}$ & ST \\
\hline Temperature $\left({ }^{\circ} \mathrm{C}\right)$ & 28.00 & 28.50 & 28.56 & $\mathrm{~ns}$ \\
$\mathrm{pH}$ & $6.06^{\mathrm{a}}$ & $6.34^{\mathrm{a}}$ & $5.39^{\mathrm{b}}$ & $*$ \\
Dissolved Oxygen (mg/l) & $7.71^{\mathrm{a}}$ & $6.34^{\mathrm{b}}$ & $4.23^{\mathrm{c}}$ & $*$ \\
Alkalinity (mg/l) & $136.60^{\mathrm{a}}$ & $52.40^{\mathrm{b}}$ & $50.53^{\mathrm{b}}$ & $*$ \\
Total hardness $(\mathrm{mg} / \mathrm{l})$ & 60 & $150.40^{\mathrm{a}}$ & $115.2^{\mathrm{b}}$ & $*$ \\
Egg fertilization $(\%)$ & 95.67 & 95.22 & 97.56 & $\mathrm{~ns}$ \\
Egg hatching $(\%)$ & $92.8^{\mathrm{a}}$ & $87.3^{\mathrm{b}}$ & $68.8^{\mathrm{c}}$ & $*$ \\
Survival rate $(\%)$ & $89.89^{\mathrm{a}}$ & $50.22^{\mathrm{c}}$ & $64.44^{\mathrm{b}}$ & $*$ \\
Time to commencement of egg hatching (minutes & $1443^{\mathrm{b}}$ & $1453^{\mathrm{b}}$ & $1517^{\mathrm{a}}$ & $*$ \\
Time to termination of egg hatching (minutes) & $1962^{\mathrm{b}}$ & $1957^{\mathrm{b}}$ & $2037^{\mathrm{a}}$ & $*$ \\
\hline \multicolumn{4}{c}{ ST $=$ Statistical test; ns $=$ Not significant, $*=$ Significant at $5 \%$ level } &
\end{tabular}

Table 2: Coefficient of variation in water quality parameters within three neighbourhood boreholes

\begin{tabular}{llllll}
\hline Boreholes Parameters & $300 \mathrm{~m}$ & $400 \mathrm{~m}$ & $330 \mathrm{~m}$ & Test & Mean CV $(\%)$ \\
\hline Temperature. $\left({ }^{\circ} \mathrm{C}\right)$ & 0.091 & 0.088 & 0.088 & $\mathrm{~ns}$ & 8.9 \\
$\mathrm{pH}$ & $0.081^{\mathrm{a}}$ & $0.060 \mathrm{c}$ & $0.072^{\mathrm{b}}$ & $*$ & 7.1 \\
Dissolved Oxygen (mg/l) & $0.062^{\mathrm{c}}$ & $0.175^{\mathrm{a}}$ & $0.139^{\mathrm{b}}$ & $*$ & 12.5 \\
Alkalinity (mg/l) & $0.021^{\mathrm{c}}$ & $0.104^{\mathrm{a}}$ & $0.089^{\mathrm{b}}$ & $*$ & 7.1 \\
Total hardness (mg/l) & $0.425^{\mathrm{a}}$ & $0.115^{\mathrm{b}}$ & $0.089^{\mathrm{c}}$ & $*$ & 21 \\
\hline \multicolumn{5}{c}{$n s=$ Not significant, ${ }^{*}=$ Significant at 5\% level }
\end{tabular}

The dissolved oxygen $(7.71,6.34$ and 4.23$) \mathrm{mg} / \mathrm{l}$ of the water from the boreholes: $300 \mathrm{~m}, 400 \mathrm{~m}$ and $330 \mathrm{~m}$ in that order and their respective degree of fluctuation measured as coefficient of variations $(6.2 \%, 1.8 \%$ and $1.4 \%$ within the boreholes) were significantly different
$(\mathrm{P}<0.05)$ among the boreholes. These could be traced to the slight differences observed in temperature among the boreholes and implies that slight change in water temperature could trigger significant change in level of dissolved oxygen in water. Boyd and Tucker 
(1998) reported that solubility of oxygen in water decreases with increase in water temperature. There was significant difference $(\mathrm{P}<0.05)$ in water $\mathrm{pH}(6.06$, 6.34 and 5.39) among the boreholes and the fluctuation of $\mathrm{pH}(0.081,0.060$ and 0.072$)$ within the boreholes was also significantly different $(\mathrm{P}<0.05)$ (tables 1 and 2). These findings suggest the existence of different carbonate system in the water from the boreholes which could be due to differences in soil and rock types that surround the neighbourhood boreholes or differences in the nature of discharge of pollutants that sip into the boreholes. Drainage water from forests and marshes could be acidic due to presence of acids produced by decaying vegetation (Exploring Environment, 2004). The concentration of carbonate $\mathrm{CO}_{3}{ }^{2-}, \mathrm{HCO}_{3}{ }^{-}$and carbon dioxide $\left(\mathrm{CO}_{2}\right.$ (aqua) are the main influence on $\mathrm{pH}$ of water. High concentration of carbonate $\mathrm{CO}_{3}{ }^{2-}, \mathrm{HCO}_{3}{ }^{-}$and carbon dioxide $\left(\mathrm{CO}_{2}\right.$ (aqua) produces alkaline water, while low concentration produces acidic water (low $\mathrm{pH}$ ). The alkalinity $(136.60,52.40$ and 50.53) $\mathrm{mg} / \mathrm{l}$ and the total hardness $(60,150.40$ and 115.20$) \mathrm{mg} / \mathrm{l}$ of water from $300 \mathrm{~m}, 400 \mathrm{~m}$ and $330 \mathrm{~m}$ respectively were significantly different $(\mathrm{P}<0.05)$. The coefficient of variation in alkalinity $(0.021,0.104$ and 0.089$)$ and total hardness $(0.425,0.115$ and 0.089$)$ in the same order were also significantly different among the treatments. Alkalinity differences among the boreholes suggest differences in presence of buffering materials principally the bases $\left(\mathrm{HCO}_{3}, \mathrm{CO}_{3}\right.$ and $\mathrm{OH}^{+}$among the boreholes since bases neutralize acid. Natural buffering materials in water slow down the reduction of $\mathrm{pH}$. A rapid $\mathrm{pH}$ drop follows gradual decline as the bicarbonate buffering capacity is used up. Differences in hardness among the boreholes similarly suggest differences in the geology of the earth and rocks around the boreholes as well as the history of human activities in the area. The most fluctuating water parameter among the boreholes was total hardness $(21 \%)$. This was followed by dissolved oxygen $(12.5 \%)$ and temperature $(8.9 \%)$. The fluctuation in $\mathrm{pH}$ and alkalinity were of equal magnitude of $7.1 \%$ apart.

Clarias gariepinus egg hatching success (92.8\%, $87.3 \%$ and $68.8 \%$ in water from $300 \mathrm{~m}, 400 \mathrm{~m}$ and $330 \mathrm{~m}$ borehole respectively) was significantly different $(\mathrm{P}<0.05)$ among the boreholes (Table 3$)$. Egg hatching and larval survival increased with increase in levels of dissolved oxygen and alkalinity. On the other hand, low total hardness as low as $60 \mathrm{mg} / 1$ facilitated egg hatching and larval survival much higher than $150.40 \mathrm{mg} / \mathrm{l}$ and $115.20 \mathrm{mg} / 1$. Optimal total hardness for egg hatching was not established in this study. However, it was observed that higher fluctuation in total hardness $(42.5 \%)$ permitted higher egg hatching (92.8\%) and larval survival $(89.9 \%)$ than lower fluctuations $11.5 \%$ and $8.9 \%$ which gave $87.3 \%$, $50.2 \%$ and $68.8 \%, 50.2 \%$ respectively. Therefore inducing fluctuation in total hardness could be employed for enhanced Clarias gariepinus egg hatching. Time to commencement of egg hatching $(1443,1453$ and 1517$)$ minutes in $300 \mathrm{~m}, 400 \mathrm{~m}$ and $330 \mathrm{~m}$ waters respectively and time to termination of egg hatching (1962, 1957 and 2037) minutes in the same order were significantly different $(\mathrm{P}<0.05)$ among the treatments (Table 3 ).

Table 3: Hatching success of C. gariepnus egg in different boreholes

\begin{tabular}{lllll}
\hline Boreholes Parameters & $300 \mathrm{~m}$ & $400 \mathrm{~m}$ & $330 \mathrm{~m}$ & ST \\
\hline Egg fertilization (\%) & 95.67 & 95.22 & 97.56 & $\mathrm{~ns}$ \\
Egg hatching (\%) & $92.8^{\mathrm{a}}$ & $87.3^{\mathrm{b}}$ & $68.8^{\mathrm{c}}$ & $*$ \\
Survival rate (\%) & $89.89^{\mathrm{a}}$ & $50.22^{\mathrm{c}}$ & $64.44^{\mathrm{b}}$ & $*$ \\
Time to commencement of egg hatching (minutes & $1443^{\mathrm{b}}$ & $1453^{\mathrm{b}}$ & $1517^{\mathrm{a}}$ & $*$ \\
Time to termination of egg hatching (minutes) & $1962^{\mathrm{b}}$ & $1957^{\mathrm{b}}$ & $2037^{\mathrm{a}}$ & $*$ \\
\hline \multicolumn{4}{c}{ St $=$ Statistical test; $\boldsymbol{n} \boldsymbol{s}=$ Not significant, ${ }^{*}=$ Significant at $5 \%$ level }
\end{tabular}

Conclusion: Disparity in water quality among neighbourhood boreholes and differences in their ability to support Clarias gariepinus egg hatching were observed. The document therefore recommended carefulness in choice of water for fish propagation. Moderately hard water $(<115 \mathrm{mg} / \mathrm{l})$ was more favourable to egg hatching and larval survival than harder $(>115 \mathrm{mg} / \mathrm{l})$ or soft $(<60 \mathrm{mg} / \mathrm{l})$ waters. High coefficient of variation in hardness enhanced hatching and larval survival. Inducing fluctuation in total hardness could be employed for improved Clarias gariepinus egg hatching.

\section{REFERENCES}

Abiodun, A (1986) Issues in fish farming economics. Experiences from coastal states of Nigeria. J. of West African fish. (11):75-88

Ayoade, JO and Oyebande, BL (1983) Water resources: In JS Oguntoyinbo, OO Areola and M.Filani (1978): A Geography of Nigeria development. Heineman Ed. Nigeria, Ltd, 71$88 \mathrm{pp}$

Bhantanagar, A and Devi, P (2013) Water quality guidelines for fish management of pond fish 
culture. International journal of environmental sciences 3(6):0976-4402

Boyd, CE and Tucker, CS (1998) Pond aquaculture water quality management. Kluwer Academic Publisher, Boston, MA. 1998. 700pp

Emmanuel, CA and Solomon, RJ (2013). The growth rate and survival of Clarias gariepinus fingerlings in tap water, borehole and stream water. Academia Arena 5 (7)

Exploring Environment (2004): Water quality. www.cotf.edu/ete/modules/water q2/wqph.html.

FAO (1994): Aquaculture development and research in sub-Saharan Africa. CIFA TECHNICAL PAPER No 23 Rome, FAO, 1994

Giller, PS and Malmquisit, B (1998). The Biology of Streams and Rivers. Oxford University Press 1998. 296pp

Lee, G.F; Jones, RA;Newbry, BW (1982) Water quality standard and water quality. Journal $W P C F$ vol 54. 1131-1138

Meador. MR and RM Goldstein 2003. Assessing water quality at large geographical scales relation among land and water physiochemistry riparian condition and fish community structure. Environ. Manage. 31: 504-517

Onuoha, GC (2009). Fundamental Principles of Fisheries Science. New Edition Digital Press .Umuahia 1-274pp
Orji, RCA; Nnamdi, NC; Onyike, G; Ogbonna, J (1997): Effects of different salinity levels on the Fertilization and hatching of Hetrobranchus bidorsails NAGA The ICLARM Quarterly 21$22 p p$

Ozigbo E, Anyadike.C Adegbite, O; Kolawole, P (2014) Review of aquaculture production and management in Nigeria. Am. J. Exp. Agric. 40:1137-1151

Piper, RG; Mcelwain IB., McElwain, LE; McCraren, JP; Flower, LG and Leonard JR (1982). Fish Hatchery Management. Washington D.C.: U.S. Dept. Of the Interior, Fish and wildlife service

Tucker, CS. (1991): Water quality and quality requirement for channel catfish Hatcheries. SRAC Publication No: 461 Grant No:89-38500-45161

Shikomanov. IA (2000). Anthropogenic Effects on the Hydrological Cycle. Hydrological Cycle- vol 1 Encyclopaedia of Life Support System. 7pp

Uka A and Sikoki FD (2013) Effects of salinity on the reproduction of Tilapia guineenis in Niger Delta. .J. Aquat. Sci. 26; 43-48

Wheaton Fred (1977) Recirculating aquaculture system: An over view of waste management. Aquacultural Engineering, second printing. Robert. E. Krieger publishing company Malabar Florida. 68pp. 